INSTITUT AGAMA ISLAM IMAM GHOZALI (IAIIG) CILACAP

LPPM (Lembaga Penelitian dan Pengabdian Masyarakat)

Al-Munqidz: Jurnal Kajian Keislaman

JI. Kemerdekaan Barat No.17 Kesugihan-Cilacap || https://ejournal.iaiig.ac.id/index.php/amk Issn SK no.: 0005.235/JI.3.2/SK.ISSN/2012.07 || 0005.27158462/JI.3.1/SK.ISSN/2020.01

\title{
SISTEM AUGMENTED REALITY (AR) DALAM DAKWAH ISLAM
}

\author{
Mochamad T. A. Aziz Zein ${ }^{1}$, Ninik Agustin ${ }^{2}$ \\ Program Studi Komunikasi dan Penyiaran Islam ${ }^{1}$, Program Studi Teknik Informatika ${ }^{2}$ \\ Institut Agama Islam Imam Ghozali ${ }^{1}$, Universitas Nahdlatul Ulama Al Ghzali ${ }^{2}$ \\ Email : zein@ iaiig.ac.id, ${ }^{1}$ ninik.agustin@ gmail.com ${ }^{2}$
}

\author{
Naskah Diterima \\ 20 April 2020 \\ Publis Artikel \\ 16 Mei 2020
}

Abstrak: The Use Of Mobile Technology In The Industrial 4.0 Era Is A Must. The Number Of Smartphone Users Continues To Increase Over Time. Contiinum Reality Technology Which Consists Of Both Virtual Reality (VR) And Augmented Reality (AR) Becomes A Portable Technology That Is Easy And Affordable Being Used With A Smartphone. This Study Has An Objective To Determine The Potential Uses Of Augmented Reality (AR) Technology In Modern Islamic Da'wa. This Study Are Counted As A Literature Study Using The Traditional Review Method.

AR Applications Have Been Used In Many Fields, Such As Medical, Military, Manufacturing, Visualization, Entertainment And Games, Robotics, Education, Marketing, Navigation, Tourism, Geospatial, Urban Planning And Civil Sciences. Da'wa Requires Attention In Both Truth And Good Ability Of The Preachers. It's Based On Legal Aspects And The Procedures (Fiqhud-Dakwah). There Was Limited Amount Of Research And AR Products Used In Da'wa. The AR's Technology That Can Be Applied In Islamic Da'wa Are 1) Playing Cards For Da'wa, 2) Islamic Story Books, 3) Da'wa Brochures / Leaflets / Poster, 4) Islamic History Museum.

Keyword : Augmented Reality, Da'wa, Islam

Abstrak: Pemanfaatan Teknologi Mobile Dalam Era Industri 4.0 Merupakan Suatu Keharusan. Jumlah Pengguna Smartphone Terus Meningkat Seiring Dengan Waktu. Teknologi Realitas Contiinum Yang Terdiri Atas Virtual Reality (VR) Dan Augmented Reality (AR) Menjadi Teknologi Portable Yang Semakin Mudah Dan Terjangkau Dengan Adanya Perangkat Smartphone. Penelitian Ini Bertujuan Untuk Mengetahui Potensi Penggunaan Teknologi Augmented Reality (AR) 
Dalam Dunia Dakwah Modern. Penelitian Ini Termasuk Dalam Penelitian Literatur Menggunakan Metode Traditional Review.

Aplikasi AR Telah Digunakan Dalam Banyak Bidang. Bidang Yang Telah Memanfaatkan AR Diantaranya Adalah Medis, Militer, Manufaktur, Visualisasi, Hiburan Dan Permainan, Robotika, Pendidikan, Marketing, Navigasi, Wisata, Geospasial, Perencanaan Perkotaan Dan Ilmu Sipil. Penyampaian Dakwah Memperhatikan Kebenaran Dan Kemampuan Yang Baik Penyampainnya Berdasarkan Aspek Hukum Dan Tatacara Penyampaiannya (Fiqhud-Dakwah). Terdapat Keterbatasan Jumlah Riset Dan Produk AR Yang Telah Digunakan Dalam Menerapkan Metode Dakwah. Potensi AR Yang Dapat Diterapkan Dalam Metode Dakwah Islam Adalah 1) Kartu Bermain Konten Dakwah, 2) Buku Cerita Tentang Dakwah Islam, 3) Brosur/Leaflet/Poster Dakwah, 4) Museum Sejarah Islam.

\section{Kata Kunci : Augmented Reality, Dakwah, Islam}

\section{A. Pendahuluan}

Perkembangan teknologi sangat pesat dirasakan oleh Negara Indonesia saat ini. Peningkatan penggunaan e-commerce, e-government serta berbagai aplikasi yang memanfaatkan interaksi teknologi dalam masyarakat menjadi indikasi bahwa Indonesia saat ini telah masuk dalam era Industri 4.0 (Kemenperin, 2018; Puspita, Fitriani, Astuti, \& Novianti, 2020). Pemanfaatan teknologi mobile dalam era Industri 4.0 merupakan suatu keharusan. Teknologi mobile dapat diartikan sebagai suatu perangkat Internet of Things (IoT) yang menjadi bagian dari era ini. Peningkatan pengguna mobile ini diimbangi dengan berbagai perkembangan teknologi yang memanfaatkan perangkat jenis ini. Teknologi Realitas Contiinum yang terdiri atas Virtual Reality (VR) dan Augmented Reality (AR) menjadi teknologi portable yang semakin mudah dan terjangkau dengan adanya perangkat smartphone.

Penelitian ini membahas mengenai perkembangan teknologi Realitas Continuum khususnya pada teknologi Augmented Reality (AR). Pembahasan difokuskan pada mekanisme kerja, sejarah perkembangan, metode dakwah, implementasi AR pada berbagai bidang dan potensi penggunaan AR pada bidang dakwah di masa mendatang. Penelitian ini bertujuan untuk mengetahui potensi penggunaan teknologi Augmented Reality (AR) dalam dunia dakwah 
modern. Potensi ini akan dimanfaatkan dalam peningkatan efektivitas dan pengembangan metode dakwah Islam.

\section{Metode Traditional Review}

Traditional review adalah metode penelusuran berbagai pustaka dengan pemilihan paper ilmiah berdasarkan pengetahuan spesifik dari peneliti. Literatur review adalah evaluasi kritis terhadap penelitian-penelitian sebelumnya pada suatu topik penelitian dengan merangkum, menganalisis dan mensintesis isinya serta menyajikannya dalam suatu survei paper (Wahono, 2016). Penelitian ini termasuk dalam penelitian literatur menggunakan metode traditional review. Penelusuran bahan kajian (paper) dan produk AR dalam dakwah islam berdasarkan pada kategorisasi konten paper (yang berhubungan dengan AR dalam dakwah islam). Proses penelitian meliputi 1) Penentuan tema kajian, 2) Penelusuran paper dan produk, 3) Eliminasi/filtering paper dan produk berbasis AR, 4) Rekapitulasi hasil eliminasi, 5) Pembahasan dan analisis, 6) Penulisan. Eliminasi produk ataupun bahan kajian (paper) dilakukan dengan tujuan untuk peningkatan kualitas kajian tulisan.

\section{B. Pembahasan}

Indonesia menduduki peringkat 5 (lima) dunia jumlah pengguna perangkat smartphone. Gambar dibawah ini menunjukkan ranking pengguna smartphone di seluruh dunia.

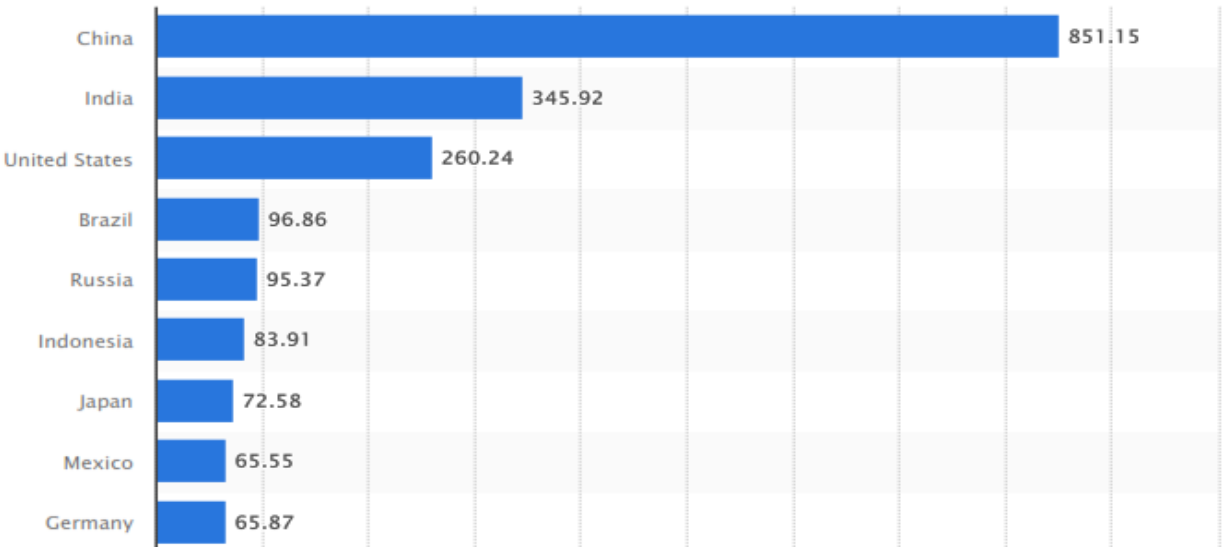

Gambar 1 Pengguna Smartphone di Dunia (dalam juta jiwa). Sumber : https://www.statista.com/statistics/748053/worldwide-top-countries-smartphone-users/

Jumlah pengguna smartphone terus meningkat seiring dengan waktu. Penggunaan smartphone ini menjadi pintu masuk teknologi AR. Perangkat AR yang murah dan mudah 
diimplementasikan adalah smartphone dengan spesifikasi dan kriteria tertentu. Hal utama yang harus dimiliki untuk merancang sebuah sistem AR menggunakan smartphone adalah spesifikasi teknis keberadaaan sensor Accelerometer dan Gyroscope, Sistem Android (sesuai kebutuhan dalam pengembangan), GPU dan RAM smartphone yang mencukupi untuk menjalankan aplikasi hasil pengembangan serta kamera dengan resolusi dan daya tangkap yang baik.

Virtuality Continuum (VC)

Augmented Reality dikenal sebagai Mixed Reality (MR) yang dapat saling menghubungkan antara dunia nyata dengan dunia virtual. Secara ilustratif, penjelasan mengenai keterhubungan dua dunia ini tergambar pada skema (Milgram \& Kishino, 1994) yang telah diadaptasi sebagai berikut

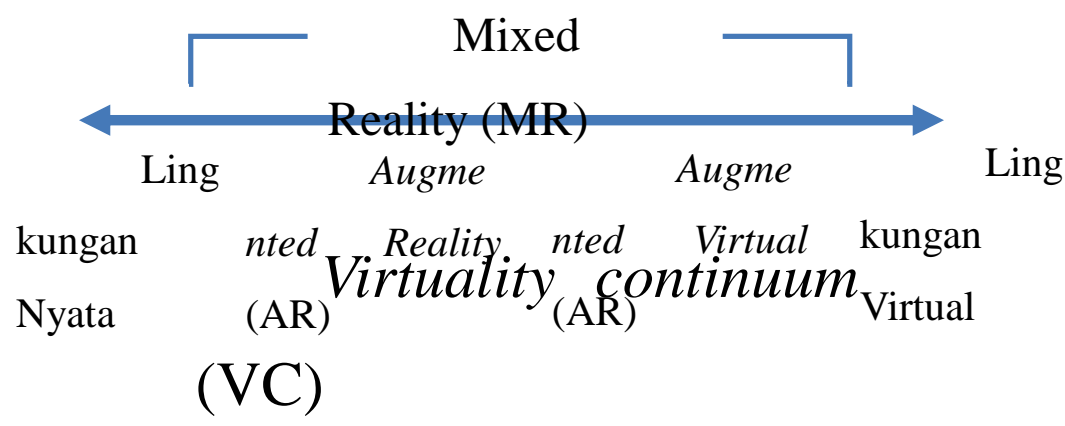

Gambar 2 Skema konsep Augmented Reality diadaptasi dari (Milgram \& Kishino, 1994)

Proses penggabungan lingkungan nyata dengan virtual memerlukan aplikasi khusus yang dibangun secara spesifik. Ide dasar dari Augmented Reality adalah membawa dunia virtual ke dalam dunia nyata melalui sebuah media perantara ataupun perangkat tertentu (smartphone). Berikut contoh nyata implementasi konsep AR dalam sebuah bentuk buku berbasis AR.

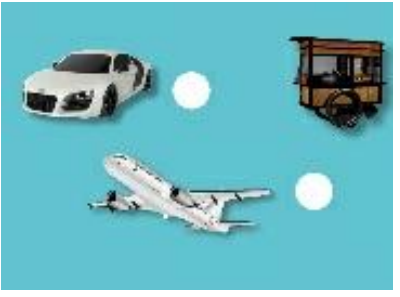

Gambar 3 Gambar 2D dalam buku yang tercetak

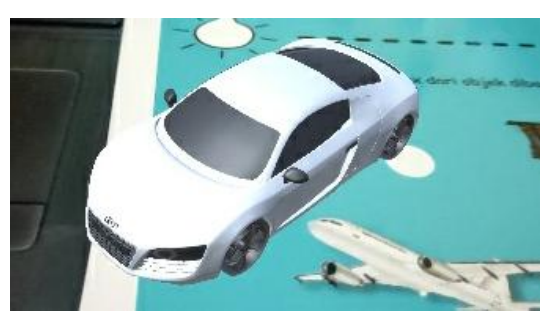

Gambar 4 Objek 3D dalam aplikasi AR melalui smartphone 
Perkembangan AR merupakan tren perkembangan masa kini yang mendapatkan ekpektasi positif dalam bidang ilmu komputer. Laporan Gartner Hype Cycle for emerging technologies 2017 (Altinpulluk, 2017) menyebutkan bahwa AR merupakan teknologi yang mendapatkan apresiasi dapat tercapai dalam kurun waktu 5 - 10 tahun seperti yang terlihat pada gambar berikut.

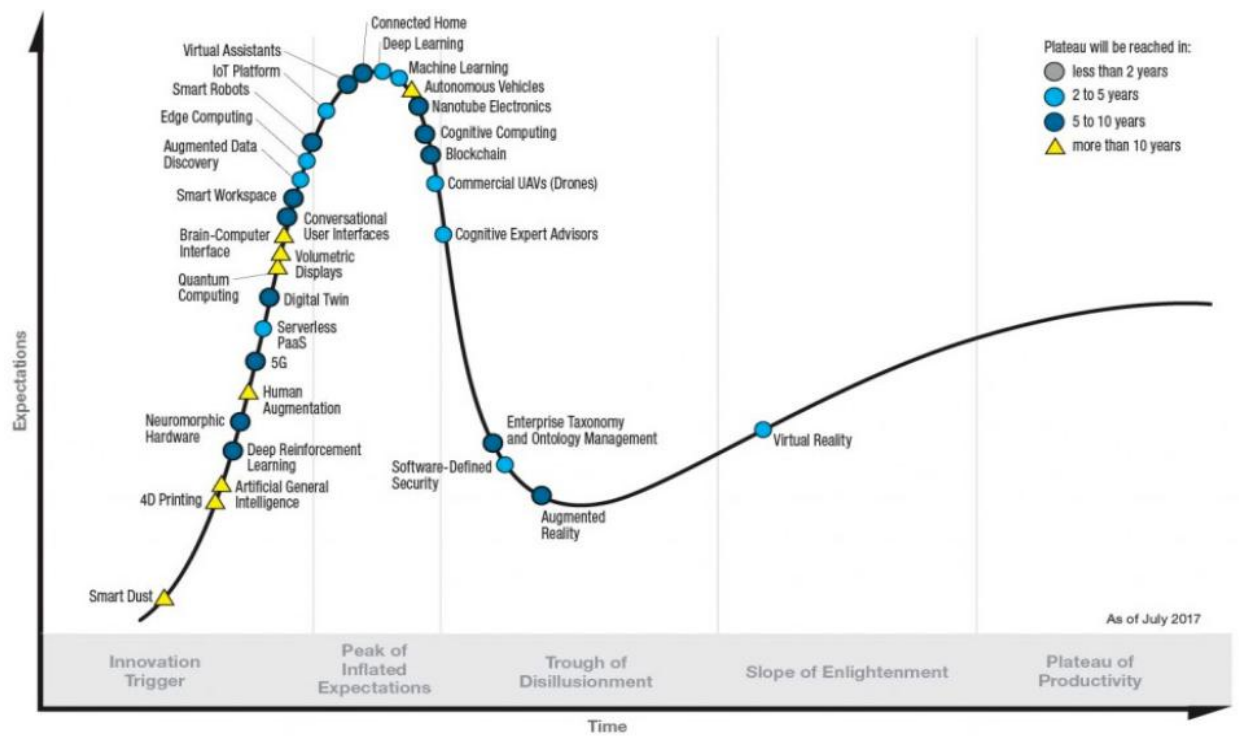

Gambar 5 Tren perkembangan Teknologi berdasarkan Laporan "Gartner Hype Cycle for Emerging Technologies 2017”' (Altinpulluk, 2017)

AR pertama kali dikembangkan pada tahun 1901 dalam buku "The Master Key" yang ditulis oleh Frank Baum. AR pada buku tersebut berupa kacamata yang digunakan untuk melihat karakteristik tokoh yang tertampil di dahi tokoh tersebut dengan tulisan baik, buruk, pintar, dan kasar (Altinpulluk, 2017). Berbagai perkembangan teknologi AR di tahun berikutnya tidak terbatas pada pengembangan buku saja. Beberapa perkembangan besar yang tercatat dalam sejarah AR dituliskan pada tabel berikut.

Tabel 1 Tabel Sejarah AR

\begin{tabular}{clllll}
\hline Tahun & \multicolumn{1}{c}{ Produk } & \multicolumn{2}{c}{ Penemu/Perusahaan } \\
\hline$(1)$ & \multicolumn{1}{c}{$(2)$} & & \\
\hline 1957 & Sensorama simulator & Morton Heilig & \\
\hline 1968 & The Sword of Damocles & Ivan Sutherland & \\
\hline 1996 & First marker-based AR System & Jun Rekimoto & \\
\hline 1997 & $\begin{array}{l}\text { Touring Machine (first mobile AR } \\
\text { System) }\end{array}$ & $\begin{array}{l}\text { Feiner, Maclntyre, Hollerer } \\
\text { Webster }\end{array}$ & and \\
\hline 1999 & $\begin{array}{l}\text { Eye Tap (The Ancestor of smart } \\
\text { glasses) }\end{array}$ & Steve Mann & & \\
\hline 2002 & AR Quake (First mobile AR game) & Thomas, Close, Donoghue, Squires, \\
\hline
\end{tabular}




\begin{tabular}{lll}
\hline & & Bondi and Piekarski \\
\hline 2008 & First AR based bionic contact lenses & Babak Parvis \\
\hline 2012 & Google Glass & Google \\
\hline 2015 & Microsoft Hololens & Microsoft \\
\hline
\end{tabular}

Sumber : (Altinpulluk, 2017)

Berdasarkan tabel di atas, klasifikasi perangkat AR yang telah dikembangkan, digolongkan menjadi tracking technology, display technology, dan input and output technology. Aplikasi AR telah digunakan dalam banyak bidang. Bidang yang telah memanfaatkan AR diantaranya adalah medis, militer, manufaktur, visualisasi, hiburan dan permainan, robotika, pendidkan, marketing, navigasi, wisata, geospasial, perencanaan perkotaan dan ilmu sipil. Meskipun telah banyak bidang yang menerapkan penggunaan AR, namun terdapat beberapa keterbatasan utama dalam sistem berbasis AR. Beberapa keterbatasan itu adalah lamanya waktu respon dalam identifikasi objek AR, kegagalan perangkat baik secara software maupun hardware (Mekni \& Lemieux, 2014).

Sistem berbasis AR dalam bidang Arsitektur, Teknik rekayasa, Konstruksi (Noghabaei, Heydarian, Balali, \& Han, 2020), Kesehatan (Lee, Kim, \& Hwang, 2019), Pendidikan (Khairuldin, Embong, Anas, Ismail, \& Mokhtar, 2019) dan bidang lainnya membutuhkan adaptasi terhadap ciri khusus suatu bidang. Beberapa bahkan perlu dikombinasikan dengan suatu konsep spesifik seperti adanya integrasi ke dalam suatu permainan.

Potensi sistem AR lebih kuat dan efektif ketika diintegrasikan dengan teknologi lain seperti dalam permainan (games). Aplikasi AR dalam games ini sangat diterima secara global terlihat berdasarkan data pengguna Pokemon Go di dunia. Lebih dari 100 juta kali aplikasi AR ini di download dalam satu bulan sejak diluncurkan. Tercatat aplikasi AR ini memberikan keuntungan lebih dari 10 Juta Dollar tiap hari dalam bulan tersebut (Altinpulluk, 2017).

\section{Metode Dakwah Islam}

Penyampaian dakwah memperhatikan kebenaran dan kemampuan yang baik penyampainnya. Penyampaian dakwah berdasarkan aspek hukum dan tatacara penyampaiannya (Fiqhud-dakwah). Dakwah (Maryatin, 2014) dikelompokkan menjadi enam metode, sebagai berikut:

1. Dakwah Fardiah

Metode dakwah Fardiah dilakukan seorang penyampai kepada satu atau beberapa orang dalam jumlah yang kecil dan terbatas. Metode dakwah fardiah biasanya terjadi tanpa 
persiapan yang matang dan tersusun secara tertib. Contoh kegiatan dakwah fardiah adalah menasihati rekan sesama muslim dalam bentuk teguran atau anjuran memberi contoh. Contoh dakwah fardiah dalam kelompok kecil diantaranya pada acara tahniah (ucapan selamat), upacara kelahiran (tasmiyah), ataupun saat mengunjungi orang sakit.

2. Dakwah Ammah

Dakwah Ammah merupakan metode dakwah menggunakan media lisan seperti pidato (khotbah) yang disampaikan kepada sekelompok orang dengan tujuan menanamkan pengaruh pada kelompok tersebut. Metode dakwah Ammah dapat dilakukan oleh perorangan ataupun organisasi yang memahami tatacara dan isi dakwah.

3. Dakwah bil-lisan

Metode dakwah bil-lisan adalah penyampaian pesan dakwah melalui lisan seperti ceramah atau komunikasi langsung antara subjek dan objek dakwah. Metode ini biasanya digunakan ketika berkaitan dengan hari ibadah seperti khutbah Jumat atau khutbah hari Raya, kajian yang disampaikan menyangkut ibadah praktis, konteks sajian terprogram, disampaikan dengan metode dialog dengan hadirin.

4. Dakwah bil-Haal

Dakwah bil al-hal adalah metode dakwah yang mengedepankan perbuatan nyata. Hal ini dimaksudkan agar si penerima dakwah (al-Mad'ulah) mengikuti jejak dan hal ihwal si Da'i (juru dakwah). Dakwah jenis ini mempunyai pengaruh yang besar pada diri penerima dakwah. Pada saat pertama kali Rasulullah SAW tiba di kota Madinah, beliau mencontohkan dakwah bil-haal ini dengan mendirikan Masjid Quba, dan mempersatukan kaum Anshor dan kaum Muhajirin dalam ikatan ukhuwah Islamiyah.

5. Dakwah bit-tadwin

Memasuki zaman global seperti saat sekarang ini, pola dakwah bit at-tadwin (dakwah melalui tulisan) baik dengan menerbitkan kitab-kitab, majalah, internet, koran, dan tulisan-tulisan yang mengandung pesan dakwah sangat penting dan efektif.

Keuntungan lain dari dakwah model ini tidak menjadi musnah meskipun sang dai, atau penulisnya sudah wafat. Menyangkut dakwah bit-Tadwim ini Rasulullah SAW bersabda, "Sesungguhnya tinta para ulama adalah lebih baik dari darahnya para syuhada". 
6. Dakwah bil hikmah

Dakwah bil hikmah merupakan metode dakwah dengan melakukan pendekatan persuasif bertahap tanpa tekanan dan paksaan sehingga objek dakwah secara sadar mampu melaksanakan dakwah atas kemauannya sendiri. Penyampaian dakwah bil hikmah perlu memperhatikan isi dakwah sesuai dengan arti kata Al Hikmah itu sendiri, yaitu valid dalam perkataan dan perbuatan, mengetahui yang benar kemudian mengamalkannya, wara' dalam dinullah, meletakkan sesuatu pada tempatnya serta menjawab dengan tegas dan tepat.

\section{Kajian Metode Dakwah}

Metode dakwah merupakan salah satu unsur dakwah selain subjek, objek, media, dan materi dakwah (Ritonga, 2019). Pengertian metode dakwah menurut Al-Bayanuni merupakan cara atau strategi yang digunakan pendakwah untuk menyampaikan dakwah. Said Bin AlAqhthani menjelaskan metode dakwah adalah ilmu yang mempelajari bagaimana cara berkomunikasi secara langsung dalam mengatasi kendala-kendalanya. Sedangkan menurut 'Abd Al-Karim Zaidan, metode dakwah merupakan ilmu penyampaian pesan dakwah dan mengatasi kendala-kendalanya (Aziz, 2009).

Menurut Toto Tasmara, metode dakwah adalah kumpulan cara yang dilakukan oleh da'i (subjek dakwah) kepada mad'u (objek dakwah) untuk mencapai tujuan dengan dasar hikmah dan kasih sayang (Tasmara, 1997)

Berdasarkan beberapa pengertian mengenai metode dakwah, dapat ditarik kesimpulan bahwa metode dakwah merupakan cara berkomunikasi subjek dakwah agar materi dakwah dapat tersampaikan kepada objek dakwah. Dasar utama metode dakwah islam tertulis dalam QS An Nahl ayat 125, sebagai berikut:

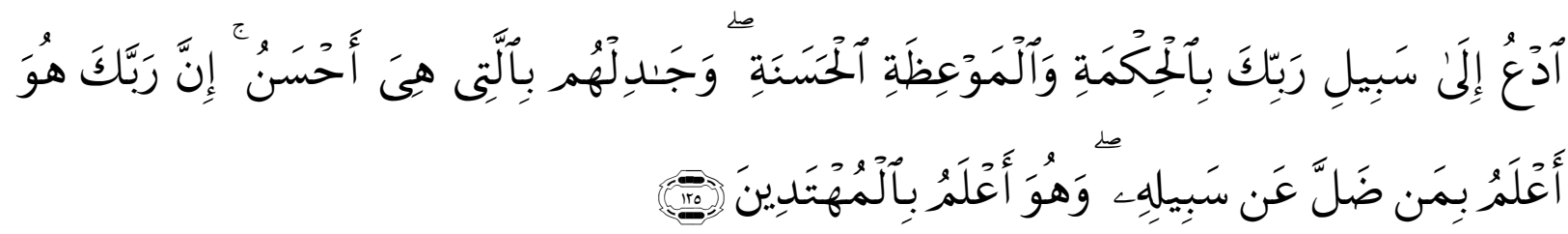

Artinya: "Serulah (manusia) ke jalan Tuhan-mu dengan hikmah dan pelajaran yang baik dan bantahlah mereka dengan cara yang baik. Sesungguhnya Tuhanmu Dialah yang lebih mengetahui tentang siapa yang tersesat dari jalan-Nya dan Dialah yang lebih mengetahui orang-orang yang mendapat petunjuk." (Departemen Agama, 1987) 
Imam Ahmad Mustofa al-Maraghi menjelaskan interpretasi Al Qur'an surah an-nahl ayat 125 didalamnya termasuk pada metode penyampaian dakwah yang merujuk pada Jurnal Al-Munzir, meliputi tiga cakupan (Ritonga, 2019), sebagai berikut:

(1) Dakwah bil hikmah

Hikmah adalah meletakkan sesuatu pada tempatnya dengan berpikir, berusaha menyusun dan mengatur dengan cara yang sesuai dengan keadaan zaman. Metode hikmah merupakan cara penyampaian dakwah yang dilakukan secara persuasif yang bertumpu pada Human Oriented, sehingga memerlukan pengakuan demokratis terhadap hak-hak manusia sebagai objek dakwah dengan tujuan fungsi dakwah sebagai informasi dari ketentuan AlQur'an tercapai (Muriah, 2000).

Metode dakwah bil-hikmah merupakan penyeruan atau pengajakan dengan cara bijak, filosofis, argumentatif, dilakukan dengan adil, penuh kesabaran dan ketabahan, sesuai dengan ajaran an-Nubuwwah dan ajaran al-Qur'an sehingga kebenaran mengenai sesuatu terposisikan secara proposional. Dakwah bil-hikmah selalu memperhatikan suasana, situasi dan kondisi objek dakwah. Oleh karena itu, metode ini menggunakan pendekatan yang relevan, realistis sesuai dengan tantangan dan kebutuhan dengan memperhatikan kadar pemikiran dan intelektual, suasana psikologis, serta situasi sosial kultural lingkungan mad'u (Enjang \& Aliyudin, 2009).

Penyampaian dakwah dengan metode bil hikmah dapat menggunakan lima bentuk bahasa dengan melihat bagaimana kondisi objek dakwah (Suparta \& Hefni, 2009), antara lain:

(a) Qoulan Baligha

Penyampaian dakwah dengan bahasa qaulan baligha (perkataan yang membekas pada jiwa) berdasarkan pada surat an-Nisa' ayat 63 dengan firmannya:

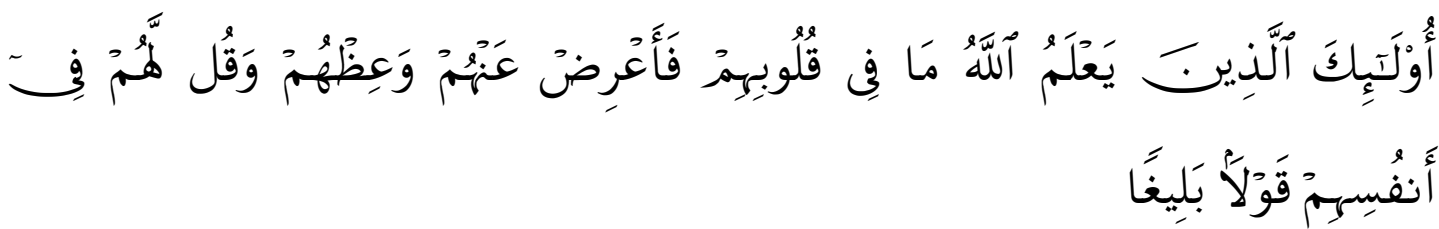

Artinya: "Mereka itu adalah orang-orang yang Allah mengetahui apa yang di dalam hati mereka. Karena itu berpalinglah kamu dari mereka, dan berilah mereka pelajaran, dan Katakanlah kepada mereka perkataan yang berbekas pada jiwa mereka" (Departemen Agama, 1987) 
Ayat di atas menceritakan mengenai penggunaan perkataan yang berbekas pada jiwa mereka (qaulan baligha) ketika menyampaikan dakwah kepada orang munafik yang diperbolehkan untuk dihindari dan diberi pelajaran.

(b) Qaulan Layyinan

Bentuk Bahasa qoulan layyinan (perkataan yang lembut) berdasarkan pada Al-Qur'an surat Thaha ayat 44 sebagai berikut:

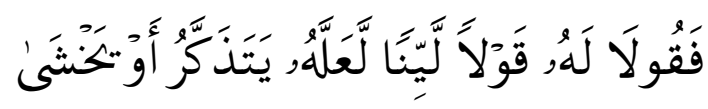

Artinya: "Maka berbicaralah kamu berdua kepadanya dengan kata-kata yang lemah lembut, Mudah-mudahan ia ingat atau takut (Departemen Agama, 1987)".

Ayat ini bercerita mengenai perintah Allah kepada Nabi Musa dan Harun untuk menyampaikan dakwah kepada Fir'aun dengan qoulan layyinan, yaitu perkataan yang bersifat sejuk dan lemah lembut.

(c) Qoulan Ma'rufan

Bahasa Qoulan ma'rufan berdasarkan pada Al-Qur'an pada surat al-Baqarah ayat 235, 2 ayat pada surat an-Nisa' ayat 5 dan 8, serta 1 ayat lagi terdapat pada surat al-Ahzab ayat 32. Salah satunya yaitu Al-Qur'an surat Al-Baqarah 2: 263 adalah sebagai berikut:

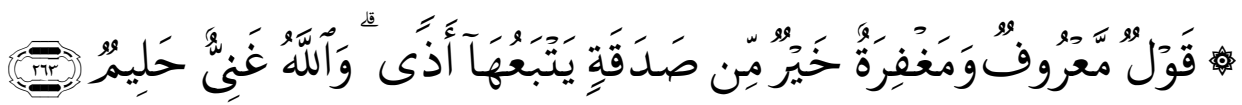

Artinya: yang baik dan pemberian maaf lebih baik dari sedekah yang diiringi dengan sesuatu yang menyakitkan (perasaan si penerima). Allah Maha Kaya lagi Maha Penyantun" (Departemen Agama, 1987)

Arti qoulan ma'rufan antara lain berupa pembicaraan yang bermanfaat, mencerahkan pemikiran, dan menunjukkan pemecahan kesulitan secara psikologis. Qoulan ma'rufan digunakan ketika berbicara tentang kewajiban orang-orang kaya atau orang kuat terhadap orang-orang yang miskin atau lemah.

(d) Qoulan Maysura

Istilah qoulan maysura berdasarkan Al-Qur'an surat Al Isra ayat 28 sebagai berikut:

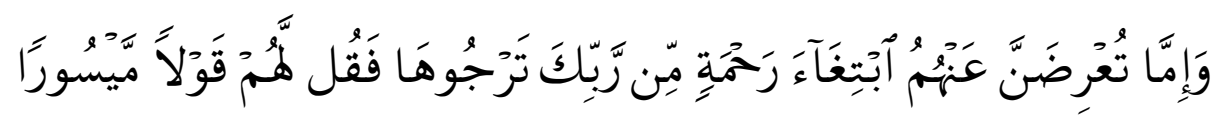


Artinya: "Dan jika kamu berpaling dari mereka untuk memperoleh rahmat dari Tuhannya yang kamu harapkan, maka katakanlah kepada mereka Qaulan Maysura (ucapan yang mudah)" (Departemen Agama, 1987)

Qoulan maysura pada ayat tersebut berarti perkataan yang ringan. Bentuk bahasa qoulan maisura yaitu bahasa yang ringan, sederhana, mudah dimengerti dan dipahami. Dakwah menggunakan Bahasa qoulan maisura ditujukan ketika objek dakwahnya adalah orang tua atau golongan tua yang sedang merasa sedih karena tindakan anak atau orang yang lebih muda kurang bijak, orang yang didzalimi oleh orang yang lebih berkuasa, dan orang yang memiliki status sosial di bawah garis kemiskinan.

(e) Qoulan Karima

Qoulan karima terdapat pada Al-Qur'an surat Al-Isra ayat 23 sebagai berikut:

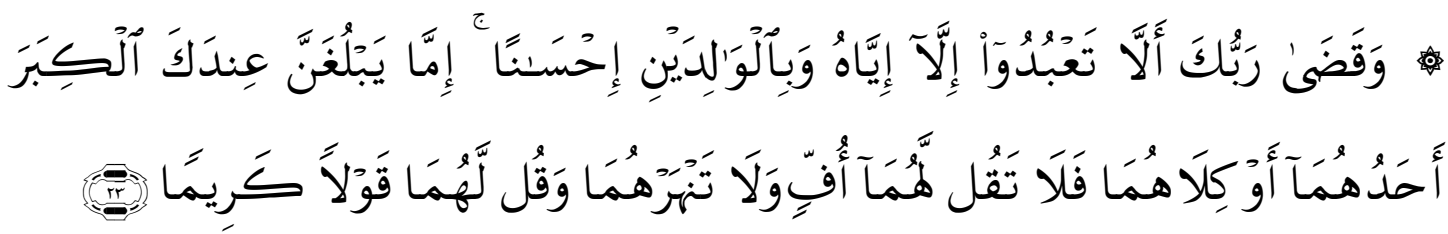

Artinya: "Dan Tuhanmu Telah memerintahkan supaya kamu jangan menyembah selain dia dan hendaklah kamu berbuat baik pada ibu bapakmu dengan sebaikbaiknya. jika salah seorang di antara keduanya atau kedua-duanya sampai berumur lanjut dalam pemeliharaanmu, Maka sekali-kali janganlah kamu mengatakan kepada keduanya perkataan 'ah' dan janganlah kamu membentak mereka dan ucapkanlah kepada mereka perkataan yang mulia" (Departemen Agama, 1987)

Qoulan karima berarti perkataan yang mulia, santun, penuh penghormatan dan penghargaan. Penggunaan bentuk Bahasa qoulan karima dalam dakwah kepada orang tua yang telah berusia lanjut.

(2) Mau'idzah hasanah

Mau'idzah hasanah menurut asal kata terdiri dari dua kata, yaitu mau'idzah dan hasanah. Mau'idzah berasal dari kata wa'adza ya'idzuwa'dzan-'idzatan yang berarti nasihat, bimbingan, pendidikan dan peringatan, sementara hasanah merupakan kebalikan dari sayyi'ah yang berarti kebaikan lawannya kejelekan (Suparta \& Hefni, 2009). Mau'idzah hasanah merupakan ungkapan yang mengandung unsur motivasi, bimbingan, pendidikan, 
pengajaran, kisah-kisah, berita gembira, peringatan, pesan-pesan positif yang bisa dijadikan pedoman dalam kehidupan agar mendapatkan keselamatan dunia dan akhirat (Munir \& Ilahi, 2006).

Metode mau'idzah hasanah digunakan dalam penyampaian dakwah bagi objek dakwah yang kapasitas intelektual dan pemikiran pengalaman spiritualnya termasuk golongan awam. Subjek dakwah berperan sebagai pembimbing dan teman dekat yang menyayangi dan memberikan segala hal yang bermanfaat serta membahagiakan objek dakwahnya (Enjang \& Aliyudin, 2009).

(3) Mujadalah

Mujadalah yaitu tukar pendapat yang dilakukan oleh dua pihak secara sinergis. Menurut mufasir al Razi mujadalah adalah bertukar pendapat yang argumentatif, tidak melahirkan permusuhan dan senantiasa saling menghormati dan menghargai perbedaan pendapat. Mujadalah sebagai metode dakwah berfungsi mengubah manusia sesuai dengan inti tujuan dakwah yaitu aktualisasi dan manifestasi imani dalam bidang kemasyarakatan yang dilaksanakan secara teratur (Aripudin, 2001). Penerapan metode mujadalah yang baik menurut Sayyid Qutub perlu memperhatikan hal-hal berikut (Muriah, 2000)

1. Tidak merendahkan pihak lawan atau menjelek-jelekkan, karena tujuan diskusi bukan untuk mencari kemenangan, melainkan menemukan kebenaran.

2. Tujuan diskusi semata-mata hanya untuk menunjukkan kebenaran agama Islam.

3. Tetap menghormati pihak lawan.

\section{Sistem AR dalam Dakwah}

Dakwah adalah bagian penting dalam dunia Islam. Islam berkembang hingga seperti sekarang in dikarenakan adanya dakwah yang dilakukan berdasarkan metode-metode diatas. Berdasarkan tren, prediksi, dan berbagai analisis yang dijelaskan sebelumnya, penggunaan teknologi berbasis AR diyakini akan terus berkembang. Hal ini terlihat dari 1) Pengguna smartphone yang semakin banyak, 2) teknologi AR yang semakin mudah diimplemantasikan, 3) penerapan AR di berbagai bidang. Pemanfaatan AR menjadi keharusan untuk mengikuti perkembangan teknologi yang sangat cepat. Prediksi penggunaan AR hingga tahun 2023 berdasarkan model yang dikembangkan dari STATISTA ditunjukkan pada gambar sebagai berikut. 


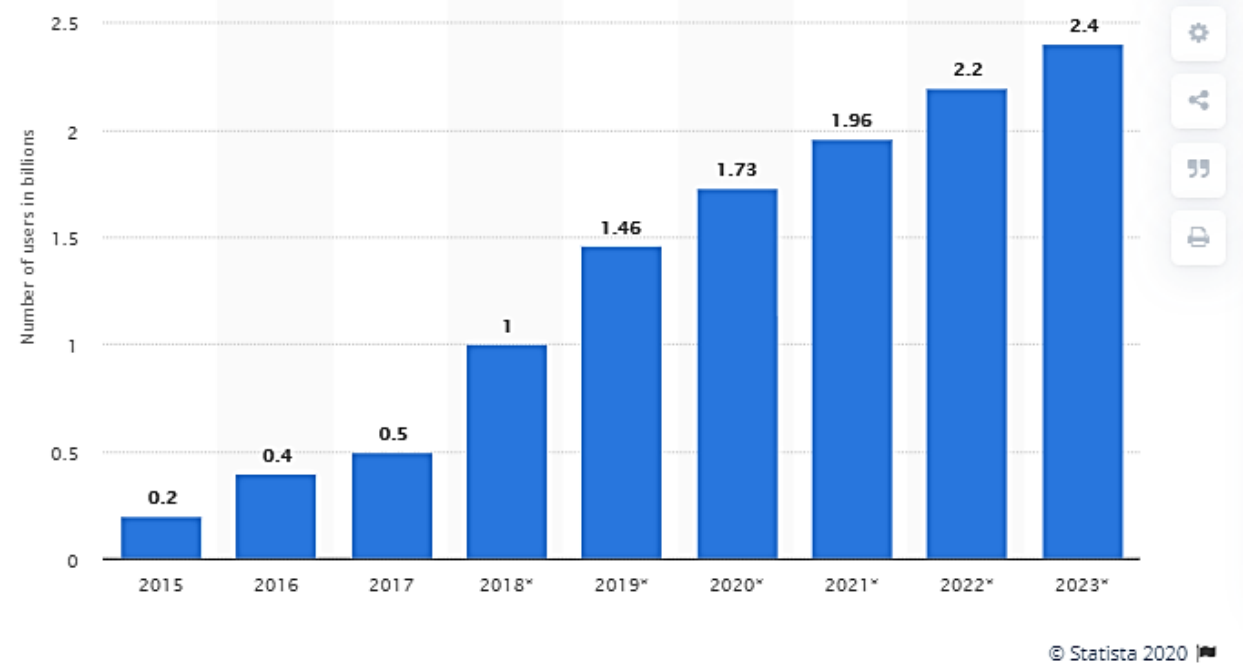

Gambar 6 Data dan prediksi Pengguna AR di seluruh dunia. Sumber :

https://www.statista.com/statistics/1098630/global-mobile-augmented-reality-ar-users/

Pengguna AR dari sejak tren kemunculan tahun 2015 telah mengalami peningkatan lebih dari 2 (dua) kali lipat pada tahun 2017. Pada tahun 2020 diprediksi telah mencapai lebih dari 8 (delapan) kali lipat dibandingkan tahun 2015. Hal ini menjadi dasar pemikiran bahwa saat ini adalah waktu yang tepat dalam implementasi AR dalam bidang dakwah. Penerapan Sistem berbasis teknologi AR yang telah diimplemantasikan dalam bidang dakwah dan keislaman diantaranya adalah sebagai berikut:

Tabel 2 Penerapan Teknologi AR di bidang dakwah dan keislaman:

\begin{tabular}{clccl}
\hline No & \multicolumn{1}{c}{ Sistem AR } & Tahun & \multicolumn{1}{c}{ Negara } & \multicolumn{1}{c}{ Developer } \\
\hline$(1)$ & \multicolumn{1}{c}{$(2)$} & $(3)$ & \multicolumn{1}{c}{$(4)$} & \multicolumn{1}{c}{$(5)$} \\
\hline 1 & AR untuk Studi Islam & 012 & Malaysia & $\begin{array}{l}\text { (Saforrudin, Zaman, \& Ahmad, } \\
2012)\end{array}$ \\
\hline 2 & $\begin{array}{l}\text { AR Book Panduan } \\
\text { Wudlu }\end{array}$ & 2016 & Indonesia & $\begin{array}{l}\text { (Setiawan , Syaripudin, \& } \\
\text { Gerhana, 2016) }\end{array}$ \\
\hline 3 & $\begin{array}{l}\text { AR untuk Hafalan Al } \\
\text { Qur'an }\end{array}$ & 2018 & Malaysia & $\begin{array}{l}\text { (Ahmad, Zainuddin, \& Yusoff, } \\
\text { 2018) }\end{array}$ \\
\hline 4 & $\begin{array}{l}\text { Sistem AR untuk Doa } \\
\text { Harian }\end{array}$ & 2019 & Malaysia & $\begin{array}{l}\text { (Khairuldin, Embong, Anas, } \\
\text { Ismail, \& Mokhtar, 2019) }\end{array}$ \\
\hline 5 & $\begin{array}{l}\text { AR Book Doa (4D) } \\
\text { Buku STORY (Short }\end{array}$ & $\begin{array}{l}\text { 2019 } \\
\text { Stories Based On }\end{array}$ & Indonesia & (Murhayati, et al., 2019) \\
\hline
\end{tabular}


Augmented Reality)

Tabel diatas menunjukkan keterbatasan jumlah riset dan produk AR yang digunakan dalam bidang dakwah islam secara umum. Produk AR lain yang beredar dan diperjualbelikan secara umum adalah Kartu AR dan Buku AR. Berdasarkan hal tersebut, potensi AR dalam bidang keislaman dapat diterapkan sebagai berikut :

1. Kartu bermain (playing cards)

Kartu bermain berbasis AR diarahkan untuk pengenalan berbagai kebutuhan dalam dunia islam seperti, pengenalan huruf hijaiyah, pengenalan tata cara suatu ibadah dan permainan edukasi islam berbasis kartu bermain .

2. Buku

Kombinasi buku dan smartphone sebagai perangkat AR adalah salah satu potensi utama penerapan AR dalam bidang dakwah islam. Buku dakwah keislaman yang biasanya $2 \mathrm{D}$ ataupun digital, diubah menjadi berbasis AR.

3. Brosur/leaflet/poster

Penerapan brosur/leaflet/poster berbasis AR adalah dengan penambahan suatu objek AR dalam kontennya sesuai dengan tema media tersebut.

4. Museum digital

Museum digital dapat berbentuk suatu lokasi yang dikombinasikan secara khusus memanfaatkan teknologi AR. Museum digital ini dapat dimanfaatkan untuk peningkatan pengetahuan tentang sejarah islam, tempat-tempat yang memiliki arti khusus dalam islam dan sebagainya

Penerapan AR diatas dapat dikategorikan sebagai bentuk metode Dakwah bit-tadwin yaitu dakwah berdasarkan tulisan. Dalam perkembangannya media dakwah tidak hanya berbentuk tulisan. Perkembangan ini mengikuti tren teknologi, adat, kebiasaan yang ada dalam suatu masa.

\section{Penutup}

Berdasarkan analisis literatur diatas dapat disimpulkan bahwa Indonesia menduduki peringkat 5 (lima) besar dunia jumlah pengguna perangkat smartphone. Penggunaan smartphone ini menjadi pintu masuk teknologi Augmented Reality (AR). Aplikasi AR telah digunakan dalam banyak bidang. Bidang yang telah memanfaatkan AR diantaranya adalah 
medis, militer, manufaktur, visualisasi, hiburan dan permainan, robotika, pendidkan, marketing, navigasi, wisata, geospasial, perencanaan perkotaan dan ilmu sipil. Tren analisis, prediksi, dan berbagai analisis meyakini bahwa penggunaan teknologi berbasis AR akan terus berkembang. Hal ini terlihat dari 1) Pengguna smartphone yang semakin banyak, 2) teknologi AR yang semakin mudah diimplemantasikan, 3) penerapan AR di berbagai bidang.

Terbatasnya jumlah riset dan produk AR yang digunakan dalam bidang dakwah menunjukkan bahwa metode dan media dakwah islam masih perlu ditingkatkan. Salah satu peningkatan itu adalah dengan penarapan AR dalam bentuk 1) Kartu bermain (playing cards), 2) Buku, 3) Brosur/leaflet/poster, 4) Museum digital

\section{Daftar Pustaka}

Ahmad, H., Zainuddin, N. M., \& Yusoff, R. C. (2018). Augmented Reality Operational Framework to Aid Al-Quran Memorization for Hearing Impaired Students. Open International Journal of Informatics (OIJI), 6(2), 94-103.

Altinpulluk, H. (2017). CURRENT TRENDS IN AUGMENTED REALITY AND FORECASTS ABOUT THE FUTURE. Proceedings of ICERI 2017 Conference (pp. 3649-3655). Seville, Spain: ICERI. doi:10.21125/iceri.2017.0986

Aripudin, A. (2001). Dakwah Antarbudya. Bandung: PT. Remaja Rosdakarya.

Aziz, M. A. (2009). Ilmu Dakwah. Jakarta: Kencana.

Departemen Agama. (1987). Tafsir Al-Qur'an. Jakarta: PT. Serayajaya Santara.

Enjang, A., \& Aliyudin. (2009). Dasar-dasar Ilmu Dakwah. Bandung: WIdya Padjajaran.

Kemenperin. (2018, 03 20). Making Indonesia 4.0: Strategi RI Masuki Revolusi Industri Ke-4. Retrieved 06 18, 2020, from Kementerian Perindustrian Republik Indonesia: https://kemenperin.go.id/artikel/18967/Making-Indonesia-4.0:-Strategi-RI-Masuki-RevolusiIndustri-Ke-4

Khairuldin, W. M., Embong, A. H., Anas, W. N., Ismail, D., \& Mokhtar, W. K. (2019). An Augmented Reality (AR) Approach in Educational Integration of Du'a in Islam. Journal of Academic Research in Progressive Education and Development, 8(1), 32-29. doi:10.6007/IJARPED/v8-i1/5498

Lee, L. N., Kim, M. J., \& Hwang, W. J. (2019). Potential of Augmented Reality and Virtual Reality Technologies to Promote Wellbeing in Older Adults. Applied Science. doi:10.3390/app9173556

Maryatin. (2014). Efektifitas Metode Ceramah dalam Penyampaian Dakwah Islam : Studi pada kelompok pengajian di Perumahan Mojosongo Permai Kabupaten Boyolali. JURNAL ILMU DAKWAH, 34(1), 103-122.

Mekni, M., \& Lemieux, A. (2014). Augmented Reality: Applications, Challenges and Future Trends. International Conference 13 th Applied Computattional Sciences (pp. 205-214). Kuala Lumpur: WSEAS.

Milgram, P., \& Kishino, F. (1994). A TAXONOMY OF MIXED REALITY VISUAL DISPLAY. IEICE Transaction on Information Systems, E77D 12(12), 1321-1329.

Munir, M., \& Ilahi, W. (2006). Manajemen Dakwah. Jakarta: Kencana. 
Murhayati, S., Abduh, M. A., Andhi, R. R., Yendra, R., Rahman, M., \& Fudholi, A. (2019). Educational Integration of Prayer in Islam using an Augmented Reality Approach. International Journal of Engineering and Advanced Technology (IJEAT), 8(5), 2085-2087.

Muriah, S. (2000). Metodologi Dakwah Kontemporer. Jakarta: Kencana.

Noghabaei, M., Heydarian, A., Balali, V., \& Han, K. (2020). Trend Analysis on Adoption of Virtual and Augmented Reality in the Architecture, Engineering, and Construction Industry. MDPI, 26(5), 1-18. doi:10.3390/data5010026

Puspita, Y., Fitriani, Y., Astuti, S., \& Novianti, S. (2020). Selamat Tinggal Revolusi Industri 4.0, Selamat Datang Revolusi Industri 5.0. Seminar Nasional Pendidikan Program Pascasarjana Universitas PGRI Palembang 2020 (pp. 122-130). Palembang: Universitas PGRI Palembang.

Ritonga, M. (2019). Penerapan Metode Dakwah Mau'idzah Hasanah di Era Hoax Milenial (Pemuda warga Puri Domas Sleman Yogyakarta). Al-Munzir, 12(1), 51-74.

Saforrudin, N., Zaman, H. B., \& Ahmad, A. (2012). Usage Concepts of Augmented Reality Technology in Islamic Study. GJAT, 2(1), 15-22.

Setiawan , E., Syaripudin, U., \& Gerhana , Y. A. (2016). Implementasi Teknologi Augmented Reality pada buku Panduan Wudhu Berbasis Mobile Android. JOIN, I(1), 28-33.

Suparta, M., \& Hefni, H. (2009). Metode Dakwah. Jakarta: Kencana Prenada.

Tasmara, T. (1997). Komunikasi Dakwah. Jakarta: Gaya Media Pratama.

Wahono, R. S. (2016, May 7). LITERATURE REVIEW: PENGANTAR DAN METODE. Retrieved from Romi Satria Wahono.net: https://romisatriawahono.net/

Zein, M. T., \& Munfaridah, T. (2020). STORY : Short Stories Based On Augmented Reality. Toleransi \& Harmoni. Cilacap: Ihya Media. 